\title{
Peningkatan Kompetensi Pedagogik Guru Madrasah Melalui Pelatihan Partisipatif Secara Daring Berbasis Heuristik
}

\author{
Yudha Andana Prawira ${ }^{1}$, Firman Nugraha ${ }^{2}$ \\ Balai Diklat Keagamaan Bandung Badan Litbang dan Diklat Kementerian Agama ${ }^{1,2}$ \\ e-mail: yudania3@gmail.com ${ }^{1}$, firmanugraha@ $\underline{\text { kemenag.go.id }}{ }^{2}$ \\ Received: 12 Januari 2021; Revised: 26 Februari 2021; Accepted: 28 April 2021 \\ DOI: http://dx.doi.org/10.37905/aksara.7.2.307-316.2021
}

\begin{abstract}
Abstrak
Penelitian ini berangkat dari masih rendahnya kompetensi pedagogik guru madrasah di Jawa Barat. Tujuannya untuk melihat makna pelatihan partispatif daring sebagai upaya peningkatan kompetensi pedagogik guru. Pelatihan secara daring selain dipandang efektif, juga dianggap tepat dimasa pandemi. Metode yang digunakan deskriptif analitik terhadap satu kelas pelatihan daring yang dilaksanakan di Balai Diklat Keagamaan bandung tahun 2020. Hasil penelitian menunjukkan adanya perbaikan hasil pelatihan berupa kompetensi pedagogik oleh peserta pelatihan berdasarkan perbedaan hasil pretes dan postes. Penelitian ini juga menemukan adanya peran motivasi peserta dalam proses pelatihan yang berkontribusi terhadap capaian hasil pelatihan tersebut. Sehingga, penelitian ini menyatakan bahwa pelatihan daring partisipatif bermakna sebagai upaya perbaikan kompetensi pedagogik guru, terutama masa pandemi.
\end{abstract}

Kata Kunci: Pelatihan Daring, Heuristik, Motivasi, Pedagogik

\begin{abstract}
This research is initiated from madrasa teachers' competence as the third-rate in West Java. This study aims to explore sense of online training participants as an effort to improve teacher pedagogikal competencies. Aside from its effectiveness, online training is considered appropriate during pandemics as well. The method used is descriptive analytics against one online training class held at the Religious Training Center Bandung year 2020. The result showed an improvement in form of pedagogikal competencies based on pretest and postest scores' significance. The result also demonstrated participants' motivation during the training process which contributed to the achievement of training's results. Thus, this research concludes participatory online training is a meaningful exertion in terms of improving teacher pedagogikal competencies, notably when the pandemic hit..
\end{abstract}

Keywords: e-learning, heuristik, motivation, pedagogik

\section{PENDAHULUAN}

Hasil uji kompetensi guru di Provinsi Jawa Barat pada tahun 2019 rata-rata di bawah 70, karena itu masih dianggap rendah dibawah standar penilaian nasional. Data Kemdikbud pada Neraca Pendidikan Nasional untuk Provinsi Jawa Barat nilai uji kompetensi aspek pedagogik 54,36, aspek profesional 60,95, dan rata-ratanya adalah 58,97 (Kemdikbud, 2019). Hal ini juga diungkapkan pada laporan (Paramita, 2018). Demikian pula beberapa penelitian lain tentang kompetensi pedagogik guru seperti 
(Yasin, 2011), (Habibullah, 2012), (Nilasari, 2020) dan (Junaid \& Baharuddin, 2020). Kondisi seperti ini tentu saja sangat mengkhawatirkan untuk dunia pendidikan Indonesia. Guru sebagai ujung tombak pemupuk generasi bangsa perlu dibekali dengan kemampuan yang mumpuni. Guru yang mumpuni akan mampu mendorong proses pembelajaran yang menuntun peserta didik pada kompetensi yang diharapkan.

Kompetensi pedagogik menjadi salah satu kompetensi yang harus dimiliki oleh seorang guru sesuai dengan Peraturan Menteri Pendidikan Nasional nomor 16 tahun 2007. Kompetensi pedagogik adalah ruhnya seorang guru pada saat mengajar. Secara definisi pedagogik dapat diartikan sebagai ilmu mendidik atau ilmu pengajaran (KBBI.web.id). Sementara itu menurut Langeveld dalam Fadilah menyatakan bahwa pedagogik sebagai proses pemberian bimbingan dan bantuan rohani kepada orang yang belum dewasa (Fadilah, 2015). Selanjutnya, Langeveld menyatakan bahwa pendidikan baru terjadi ketika anak mengenal kewibawaan, yang terbagi atas dua bagian, yaitu bagian batas bawah adalah peserta didik mengenal kewibawaan dari pendidiknya. Sementara batas atasnya adalah ketika tujuan pembelajaran telah tercapai. Kalimat Langeveld ini dapat dimaknai bahwa keberhasilan pendidikan dalam sudut pandang pedagogik ketika pendidik sudah dipatuhi dan memiliki kewibawaan dihadapan peserta didik. Hal tersebut bisa dikatakan sudah mencapai separuh keberhasilan dalam pendidikan. Sementara ketercapaian tujuan pembelajaran hanya sekedar dampak dari kewibawaan pendidik.

Beberapa penelitian tentang pentingnya kompetensi pedagogik seorang guru antara lain yang dikemukakan (Habibullah, 2012), (Balqis, Ibrahim, \& Ibrahim, 2014), (Fadilah, 2015), (Saputra, 2017), dan (Nilasari, 2020). Dari penelitian-penelitian tersebut menunjukkan bahwa kompetensi pedagogik guru sangat penting dalam pembelajaran. Namun kompetensi pedagogik yang menyentuh pada aspek jiwa guru adalah sebagaimana yang dikemukakan Az-Zarnuji dan Brubacher dalam Prawira bahwa mendidik dan mengajar merupakan the art of education (Y. A. Prawira, 2019). Guru yang berkompetensi dalam aspek pedagogik mendidik dan mengajar merupakan panggilan hati bukan sekedar pekerjaan, karena itu membutuhkan seni.

Permasalahan yang tersisa berikutnya adalah bagaimana caranya mengembangkan kompetensi pedagogik ini agar sesuai dengan harapan Peraturan Menteri Pendidikan, bahwa kompetensi pedagogik guru antara lain memahami karakteristik peserta didik usia sekolah dasar yang berkaitan dengan aspek fisik, intelektual, sosial-emosional, moral, spiritual, dan latar belakang sosial-budaya (Mendikbud, 2007). Menurut peraturan Menteri Pendidikan dan kebudayaan kompeten pedagogik antara mencakup (1) Pemahaman wawasan atau landasan kependidikan, (2) Pemahaman terhadap peserta didik, (3) Pengembangan kurikulum atau silabus, (4) Perancangan pembelajaran,(5) Pelaksanaan pembelajaran yang mendidik dan dialogis, (6) Pemanfaatan teknologi pembelajaran, (7) Evaluasi hasil belajar, (8) Pengembangan peserta didik untuk mengaktualisasikan berbagai potensi yang dimilikinya (Mendikbud, 2007).

Salah satu jawaban untuk mengembangkan kompetensi pedagogik seorang guru adalah melalui pelatihan untuk guru. Namun saat ini sedang dalam kondisi Pandemi Covid-19, yang secara umum sangat riskan untuk melaksanakan pelatihan guru secara tatap muka. Maka pelatihan yang dilaksanakan juga secara daring. Pelatihan secara daring ini dikenal pula dengan istilah distance learning and teaching. Sehingga 
dirasakan ada kendala ketika akan meningkatkan kompetensi pedagogik guru melalui pelatihan yang dilaksanakan secara tatap muka. Beberapa penelitian tentang pelatihan dan pembelajaran jarak jauh atau distance learning antara lain (Strungă, 2015), (Hambatan \& Jarak, 2020), (Jamaluddin, Ratnasih, Gunawan, \& Paujiah, 2020), dan (Kompas, 2020). Pelatihan guru secara daring ini tentunya memiliki beberapa karakteristik unik yang akan berbeda sekali dengan pelatihan secara tatap muka. Karena itu, dibutuhkan Teknik khusus untuk pelatihan secara daring ini.

Penelitian ini memandang bahwa pelatihan secara daring dapat lebih bermanfaat pada masa pandemik Covid-19 (Riyan, 2020), (Rizaldi, 2020). Pelatihan partisipatif secara definisi dapat dikemukakan sebagai dalam pembelajaran dengan pendekatan partisipatif andragogis keterlibatan aktif warga belajar menjadi mutlak adanya pada proses pembelajaran orang dewasa. Hal ini dilakukan mengingat warga belajar adalah orang dewasa yang sudah memiliki pengetahuan, pengalaman dan keterampilan awal, sehingga dalam proses pembelajaran lebih memperhatikan prinsip-prinsip pendidikan orang hal ini sebagaimana temuan-temuan pada penelitian tentang pelatihan partisipatif, antara lain sebagaimana yang dikemukakan (Iskandar Palopa, 2015), (Mawardi, Kristin, Anugraheni, \& Rahayu, 2019), dan (Nastiti, 2017). Semua penelitian tersebut menunjukkan hasil yang positif sebagai hasil pelatihan partisipatif.

Penelitian ini ingin menunjukkan pengembangan pelatihan partisipatif sebagaimana yang telah dilakukan peneliti lainnya namun dengan pengembangan unsur heuristik dalam proses pelatihan partisipatif. Lalu apakah manfaat pengembangan heuristiknya dalam pelatihan partisipatif. Secara operasional heuristik diartikan Darma dan Sujadi sebagai pembelajaran matematika yang menitikberatkan pada aktivitas belajar, membantu dan membimbing peserta jika menemui kesulitan dan membantu mengembangkan kemampuan pemecahan masalahnya (Sujadi, 2014). Ditinjau dari proses pembelajaran heuristik Polya Schoenfeld dalam Abdul dalam bukunya How to Solve It pertama kali mengenalkan 4 langkah dalam pemecahan masalah yang disebut Heuristik. Strategi berpikir pemecahan masalah menurut Polya dijadikan sebagai model umum strategi pemecahan masalah (Abdul \& Lidinillah, 2006). Keempat Langkah tersebut adalah (1) pemahaman terhadap permasalahan; (2) Perencanaan penyelesaian masalah; (3) Melaksanakan perencanaan penyelesaian masalah; dan (4) Melihat kembali penyelesaian (Abdul \& Lidinillah, 2006).

Dengan demikian antara pelatihan partisipatif daring dengan heuristik diharapkan peserta pelatihan dapat berperan dan berpartisipasi aktif selama pelatihan dalam menyelesaikan masalah tentang pengembangan kompetensi pedagogik guru. Berkenaan dengan latar belakang tersebut, maka penelitian ini berjudul Pengembangan Kompetensi Pedagogik Guru Madrasah melalui pelatihan partisipatif secara daring berbasis heuristik.

\section{METODE}

Penelitian ini menggunakan metode deskriptif analitik karena ingin menelusuri kebermaknaan pelatihan partisipatif yang dilaksanakan secara daring berbasis heuristik. Kritik yang ingin direspons dalam penelitian ini menyangkut masih lemahnya kompetensi pedagogik guru. Sejalan dengan hal ini, yang menjadi subjek penelitian adalah peserta pelatihan jarak jauh secara daring oleh guru madrasah di Jawa Barat yang diselenggarakan oleh Balai Pendidikan dan Pelatihan Keagamaan Bandung pada tahun 
2020. Subjek penelitian ditentukan secara purposif pada satu kelas pelatihan daring dengan jumlah peserta sebanyak 30 orang.

Adapun rancangan dalam penelitian ini dilakukan tes sebanyak dua kali, yaitu sebelum diberi perlakuan yang disebut pretes dan sesudah diberi perlakuan yang disebut postes. Menurut Sugioyono penelitian yang digunakan adalah one group pretestposttest design (Sugiyono, 2004). Adapun secara teknis pelaksanaan penelitian dengan menerapkan one group pretest-posttest design. Rumusan penelitian studi kasus ini merujuk pada pendapat Hartley (Hartley, 1976). Hal ini sesuai dengan pendapat Cannon bahwa berdasarkan studi kasus Indonesia dan analisis teoritis, rekomendasi dikembangkan untuk lembaga bantuan yang berencana melaksanakan program pengembangan profesional, dibutuhkan pelatihan untuk profesional yang ingin mengembangkan dirinya (Cannon \& Hore, 2016). Sementara itu, Yin dalam Chetty mendefinisikan one group pretest-posttest design sebagai pencarian secara empirik, yang mencakup penelitian terhadap fenomena nyata sesuai konteks, batas antara fenomena dan konteks tidak jelas dan di mana berbagai sumber bukti digunakan. kasus tunggal atau ganda dapat dipelajari (Chetty, 1996). Pendapat yang mirip juga disampaikan Malmberg bahwa one shot merupakan model penerapan hipotesis satu tembakan, dan peran penyimpanan konteks sebagai penghubung antara episodik dan semantik dibahas. (Malmberg \& Shiffrin, 2005). Penafsiran lain juga dilakukan menggunakan tabel ketentuan sebagai berikut:

Tabel 1. Interpretasi terhadap koefesien korelasi

\begin{tabular}{ll}
\hline Interval koefesien korelasi & Tingkat Hubungan \\
\hline $0.00-0.199$ & Sangat rendah \\
\hline $0.20-0.399$ & Rendah \\
\hline $0.40-0.599$ & Sedang \\
\hline $0.60-0.799$ & Kuat \\
\hline $0.80-1.00$ & Sangat Kuat \\
\hline
\end{tabular}

Sumber: diadaptasi dari Sugiyono (2008)

\section{HASIL DAN PEMBAHASAN}

Hasil

Isu kompetensi guru saat ini yang dianggap masih kurang sangat mengganjal. Beberapa laporan institusi menunjukkan hasil yang mengkhawatirkan antara lain hasil uji kompetensi guru yang dilaksanakan secara daring menunjukkan hasil yang jauh di bawah standar yang diharapkan pemerintah. Beragam upaya terus dilakukan pemerintah dengan mengeluarkan kebijakan dan peraturan. Sementara itu para akademisi melakukan beragam penelitian. Dalam penelitian ini akan dijabarkan salah salah model pelatihan guru yaitu partisipatif. Tujuannya untuk menelaah efektivitas model pelatihan partisipatif ini dalam upaya meningkatkan kompetensi pedagogik guru. Temuan yang didapat dari penelitian ini antara lain bahwa ada beberapa faktor yang bisa meningkatkan kompetensi pedagogi guru. Faktor yang terpenting adalah unsur kreativitas yang terdapat pada aspek heuristik yang terdapat pada model pelatihan partisipatif ini. Kontribusi kesadaran diri akan potensi masing-masing dan heuristik sangat membantu pada peningkatan kompetensi pedagogi, namun belum tentu 
signifikan terhadap peningkatan kinerja guru. Hal ini, karena kinerja guru memiliki karakteristik yang berbeda, dan ini akan membutuhkan instrumen yang berbeda pula.

Sesuai dengan dugaan sementara dalam penelitian ini yang ingin mengetahui peranan pelatihan partisipatif yang berbasis heuristik dengan kompetensi pedagogik guru, maka ada beberapa hal yang peneliti bisa sampaikan. Seperti yang diungkapkan dalam rancangan yaitu untuk melihat perbandingan hasil pelatihan, antara sebelum dengan sesudah mengikuti pelatihan. Hasil ini diperoleh dari pre test dan post test.

Tabel 2. Deskripsi Hasil Pre Test dan Post Test

\begin{tabular}{|c|c|c|c|c|c|c|c|}
\hline & $\mathrm{N}$ & Minimum & Maximum & \multicolumn{2}{|c|}{ Mean } & $\begin{array}{l}\text { Std. } \\
\text { eviation }\end{array}$ \\
\hline & & Statistic & Statistic & Statistic & Statistic & Std. Error & Statistic \\
\hline Pretes & & 30 & 13 & 73 & 38.03 & 2.807 & 15.375 \\
\hline Postes & & 30 & 33 & 100 & 75.73 & 4.209 & 23.056 \\
\hline $\begin{array}{l}\text { Valid } \\
\text { (listwise) }\end{array}$ & $\mathrm{N}$ & 30 & & & & & \\
\hline
\end{tabular}

Sumber: Hasil pengolahan data

Berdasarkan tabel di atas terlihat bahwa nilai pretes terrendah adalah 13 dan tertingginya adalah 73 . Sementara itu nilai postes terrendah adalah 33 dengan nilai tertinggi mencapai angka 100. Dengan demikian, secara umum dapat dijelaskan bahwa pelatihan ini memberikan dampak positif bagi peserta. Dengan adanya peningkatan hasil postes dibandingkan dengan pretes berarti ada proses belajar yang dilakukan oleh peserta selama pelatihan berlangsung.

Hasil tersebut masih memiliki kemungkinan lain bahwa walaupun dari hasil pretes dan postes menunjukkan hasil yang positif, namun kemampuan guru secara akademik tentang kepedagogikan ini apakah merupakan hasil pelatihan partisipatif atau ada hal lain yang menjadikan hasil postesnya peserta menunjukkan positif. Karena itu, masih dibutuhkan data lainnya yang bisa menunjukkan bahwa setelah mengikuti pelatihan partisipatif secara heuristik ini, Data berikutnya yang didapatkan adalah dari aspek motivasi mengikuti diklat.

Pengujian model pelatihan partisipatif heuristik, dengan perubahan kompetensi pedagogik guru sebagai peserta pelatihan, maka dilihat dari data motivasi mereka selama pelatihan dan kompetensi yang dicapai setelah mengikuti pelatihan.

Tabel 3. Hubungan Motivasi Dengan Kompetensi Peserta Pelatihan Daring

\begin{tabular}{llrr}
\hline & & Kompetensi & \multicolumn{1}{c}{ Motivasi } \\
\hline Pearson & Kompetensi & 1.000 & .270 \\
\cline { 2 - 4 } Correlation & Motivasi & .270 & 1.000 \\
\hline \multirow{2}{*}{ Sig. (1-tailed) } & Kompetensi & .075 \\
\cline { 2 - 4 } & Motivasi & .075 & .07 \\
\hline \multirow{2}{*}{$\mathrm{N}$} & Kompetensi & 30 & 30 \\
\cline { 2 - 4 } & Motivasi & 30 & 30 \\
\hline
\end{tabular}

Sumber: Hasil Pengolahan Data

Berdasarkan tabel 3 di atas, tampak bahwa kompetensi memberikan nilai 0.270 dalam mengoreksi kompetensi peserta. Angka ini jika dibaca dengan tabel 1, maka menunjukkan posisi yang rendah. Hal ini menjelaskan bahwa keberhasilan belajar mereka bukan hanya 
diisi dari aspek motivasi melainkan juga ada aspek-aspek lainnya. Aspek lainnya yang bisa turut meningkatkan hasil pelaksanaan diklat adalah pola atau bentuk diklat yang dilaksanakan bisa pula turut dalam meningkatkan kompetensi pedagogik peserta diklat.

Aspek lain dalam pelatihan sebagai sebuah sistem di dalamnya akan ada unsur pelatih yaitu widyaiswara, unsur alat atau media yang digunakan untuk pelatihan daring, juga ketersediaan sumber belajar yang lebih kaya. Dengan demikian dapat disebutkan bahwa kecenderungan peningkatan hasil pelatihan partisipatif secara heuristik lebih kepada pola pelatihan dibandingkan dengan motivasi mengikuti diklat.

\section{PEMBAHASAN}

Terjadinya peningkatan hasil tes oleh peserta pelatihan daring menunjukkan bahwa program ini dapat dianggap efektif sebagai upaya peningkatan kemampuan peserta, terutama di tengah keterbatan pola klasikal tatap muka, hal ini sebagaimana temuan penelitian Nastiti (2017). Senada dengan itu juga seperti yang ditunjukkan oleh Hanurani, H. (2019) dan Riyan, D. (2020). Dengan kata lain pelatihan daring dengan model partisipatif ini dapat dilakukan dan dilanjutkan sebagai salah satu jalan keluar untuk terus meningkatkan kompetensi para pesertapelatihan, termasuk guru.

Peningkatan hasil test dalam pelatihan ini dapat dsebutkan karena terjadinya proses belajar oleh peserta. Proses belajar yang terjadi dalam pelatihan daring ini dapat dipetakan pada beberapa hal. Pertama, peserta memiliki motivasi yang cukup untuk dapat mengikuti seluruh program pelatihan. Hal ini dapat dibaca bahwa mereka mengikuti pelatihan secara daring ini mendapatkan benefit berupa kompetensi dan sertifikat. Berbeda dengan pola klasikal di kampus, mereka para peserta memiliki benefit berganda. Sebagai lembaga pelatihan pemerintah, maka selalu dianggarkan bagi para peserta pelatihan ini sejumlah pos penggantian untuk kesejahteraan mereka. Diantaranya sarana asrama dengan kebutuhan kesehariannya seperti makan minum, snack dan fasilitas lainnya untuk belajar seperti tas dan peralatan tulis. Kemudian penggantian transport mereka sebagai pelaksana perjalanan dinas. Selain itu juga diberikan uang harian selama mereka mengikuti pelatihan. Jika membandingkan dengan kondisi benefit yang berbeda, namun ternyata mereka antusiasme untuk mengikuti pelatihan daring yang tinggi, bahkan biaya pulsa hanya terbatas dari lembaga pelatihan. Kondisi ini menunjukkan hasil penelitian (Setiawati, 2010) menemukan konteksnya yang serupa.

Meskipun berdasarkan perhitungan di tabel 2 bahwa korelasi motivasi terhadap kompetensi ada di level rendah, namun motivasi belajar sangat penting sebagai modal keberhasilan mengikuti program. Nugraha (2013) menilai bahwa sejalan dengan prinsip belajar orang dewasa, motivasi mereka akan meningkat untuk belajar jika relevan dengan pekerjaannya. Para guru yang mengikuti pelatihan daring ini dapat dibaca memiliki motivasi besar karena mereka memandang penting dengan tawaran kompetensi yang dijanjikan dalam program pelatihan ini. Berkenaan dengan hal ini beberapa penelitian tentang motivasi yang dikaitkan dengan kinerja, antara lain (Hafid, 2017), (Damanik, 2018), (Ardiana, 2017).

Orang dewasa belajar dalam situasi yang egaliter, bebas dan terbuka. Pelatihan daring memberikan ruang yang luas bagi peserta pelatihan untuk mengeksplorasi potensi mereka dengan mencari sumber belajar yang lebih kaya dari internet atau lainnya. Posisi widyaiswara berperan sebagai motivator dan coach selama pelatihan 
berlangsung (Nugraha, 2020). Dengan suasana pembelajaran yang memberikan andil terbesar pada peserta, maka konstruksi andragogi semakin kuat. Atas dasar hal tersebut, maka bisa dipahami jika kemudian terdapat semangat belajar sekaligus mengoreksi hasil tes sebelum dengan sesudah mengikuti pelatihan.

Kedua, motivasi ini juga dapat diperbaiki dengan alat yang digunakan. Dhika dkk. (2020) menemukan bahwa aspek kemudahan penggunaan learning management system sebagai support system dalam pembelajaran daring juga berpengaruh terhadap perilaku pengguna untuk memanfaatkannya. Terkait dengan ini, pelatihan daring di Balai Diklat Keagamaan Bandung menggunakan moodle versi 3.80 yang disinyalir memberikan kemudahan untuk pengguna (Restendi, Nugraha dan Trianto, 2020). Dengan demikian, faktor penggunaan dan pilihan teknologi untuk membantu pelaksanaan pelatihan daring pola e-learning inipun merupakan hal yang penting sebagai bagian dari keberhasilan program.

Sebagai sebuah program pelatihan, maka di dalamnya akan terdapat unsur-unsur yang saling berkaitan (Dally, 2011). Selain pilihan alat atau sarana, kurikulum, sesungguhnya ada subsistem yang lain yang akan turut mengoreksi motivasi peserta dalam pelatihan. Widyaiswara yang terlibat dalam pelatihan tentu tidak dapat diabaikan. Keberadaanya sebagai mitra belaajr bagi peserta akan membantu aspek-aspek penting dalam pencarian sumber, bahan dan pengayaan informasi lainnya untuk meningkatkan kompetensi peserta.

\section{PENUTUP}

Penelitian ini menyimpulkan bahwa pelatihan daring model partisipatif memberikan dampak positif bagi peserta, terutama dalam memperbaiki kompetensi paedagogik mereka. Sesuai dengan temuan dalam penelitian, suasana pembelajaran daring menguatkan konstruksi andragogi. Saalain itu ketersediaan alat yang mudah untuk digunakan akan mengoreksi motivasi peserta selama mengikuti program. Proses belajar mereka akan semakin baik dan pada gilirannya meningkatkan hasil belajar yang yang bermakna juga memperbaiki kompetensi mereka dibandingkan dengan sebelum mengikuti program pelatihan.

\section{DAFTAR PUSTAKA}

Abdul, D., \& Lidinillah, M. (2006). Heuristik dalam pemecahan masalah matematika dan pembelajarannya di sekolah dasar, 1-11.

Ardiana, T. E. (2017). Pengaruh Motivasi Kerja Guru Terhadap Kinerja Guru Akuntansi Smk Di Kota Madiun. Jurnal Akuntansi Dan Pajak, 17(02), 14-23. https://doi.org/10.29040/jap.v17i02.11

Balqis, P., Ibrahim, N., \& Ibrahim, S. (2014). Kompetensi Pedagogik Guru Dalam Meningkatkan Motivasi Belajar Siswa Pada Smpn 3 Ingin Jaya Kabupaten Aceh Besar. Jurnal Administrasi Pendidikan : Program Pascasarjana Unsyiah, 2(1), 25-38.

Cannon, R., \& Hore, T. (2016). The long - term effects of ' one - shot' professional development courses: An Indonesian case study. International Journal for Academic Development, (August). https://doi.org/10.1080/1360144970020104

Chetty, S. (1996). Case study methode small and medium research. Retrieved from 
https://journals.sagepub.com/doi/abs/10.1177/0266242696151005?journalCode= isbb

Damanik. (2018). Pengaruh motivasi dan pengembangan diri terhadap prestasi kerja dosen. Jurnal EK\& BI, 1(1), 20-28. Retrieved from http://jurnal.murnisadar.ac.id/index.php/EKBI/article/view/42

Dally, Dadang. (2011). Membangun Lembaga Diklat Yang Kredibel. Tatar Pasundan: Jurnal Diklat Keagamaan (5) 12.

Dhika, H., Destiawati, F., Surajiyo, S., \& Jaya, M. (2020, July). Implementasi Learning Management System Dalam Media Pembelajaran Menggunakan Moodle. In Prosiding Seminar Nasional Riset Information Science (SENARIS) (Vol. 2, pp. 228-234).

Fadilah, N. (2015). KOMPETENSI PEDAGOGIK GURU DALAM PEMBELAJARAN PPKN UNTUK PENCAPAIAN KOMPETENSI SIKAP SPIRITUAL DAN SOSIAL PESERTA DIDIK. Perpustakaan Universitas Pendidikan Indonesia, 13-72. Retrieved from http://repository.upi.edu/17064/5/T_PKN_1302203_Chapter2.pdf

Habibullah, A. (2012). Kompetensi Pedagogik Guru. EDUKASI: Jurnal Penelitian Pendidikan Agama Dan Keagamaan, 10(3). https://doi.org/10.32729/edukasi.v10i3.169

Hafid, M. (2017). Pengaruh Motivasi dan Kompetensi Guru Terhadap Kinerja Guru Sekolah dan Madrasah di Lingkungan Pondok Pesantren Salafiyah Syafi'iyah Sukorejo. Jurnal Pendidikan Islam Indonesia, 1(2), 293-314. https://doi.org/10.35316/jpii.v1i2.55

Hambatan, M., \& Jarak, P. (2020). Indonesia di Masa Krisis Covid-19, 19(2), 1-9.

Hanurani, H. (2019). PENINGKATAN KOMPETENSI PROFESIONAL GURU BIOLOGI MADRASAH ALIYAH MELALUI PEMBELAJARAN JARAK JAUH. Tatar Pasundan: Jurnal Diklat Keagamaan, 13(1), 10-22.

Hartley, P. J. (1976). Intoduction to basic a case study approach. New York, Dublin, London: The Macmillan Press LTD.

Iskandar Palopa. (2015). Pengembangan model pembelajaran partisipatif andragogis untuk meningkatkan hasil belajar warga belajar, 11, 59-85.

Jamaluddin, D., Ratnasih, T., Gunawan, H., \& Paujiah, E. (2020). Pembelajaran Daring Masa Pandemik Covid-19 Pada Calon Guru : Hambatan, Solusi, dan Proyeksi. LPPM UIN SGD.

Junaid, R., \& Baharuddin, M. R. (2020). Peningkatan Kompetensi Pedagogik Guru melalui PKM Lesson Study. To Maega: Jurnal Pengabdian Masyarakat, 3(2), 122. https://doi.org/10.35914/tomaega.v3i2.413

Kemdikbud. (2019). Neraca Pendidikan Daerah laporan kemdikbud .pdf. Jakarta. Retrieved from https://npd.kemdikbud.go.id/?appid=ukg

Kompas. (2020). Siswa Alami Dampak Psikologis Pembelajaran Jarak Jauh Paling Nyata. Kompas.Id, 2020. Retrieved from https://bebas.kompas.id/baca/bebasakses/2020/07/13/siswa-alami-dampak-psikologis-pembelajaran-jarak-jauhpaling-nyata/

Malmberg, K., \& Shiffrin, R. (2005). The " One - Shot " Hypothesis for Context Storage 
. Journal ArticleDatabase: APA PsycArticles, 31, 2005.

Mawardi, M., Kristin, F., Anugraheni, I., \& Rahayu, T. S. (2019). Penerapan Pelatihan Partisipatif Pada Kegiatan Penulisan Dan Publikasi Karya Ilmiah Bagi Guru SD. Scholaria: Jurnal Pendidikan Dan Kebudayaan, 9(2), 132-137. https://doi.org/10.24246/j.js.2019.v9.i2.p132-137

Mendikbud. (2007). Permendiknas No. 16 tahun 2007.

Nastiti, A. D. (2017). Pelatihan Daring dengan Model Partisipatif, VIII, 216-224.

Nilasari, K. E. (2021). THE EFFECTIVENESS OF LEARNING MODELS' TRAINING ON TEACHERS' SELF-EFFICACY AND PEDAGOGIKAL COMPETENCE. JENTRE: Journal of Education, Administration, Training and Religion, 1(1), 9-18. https://doi.org/10.38075/jen.v1i1.9

Nugraha, F. (2013). Motivasi Belajar Orang Dewasa dan Implikasinya pada Penyelenggaraan Diklat. Andragogi: Jurnal Diklat Teknis Pendidikan dan Keagamaan. 2(2): 38-49.

Nugraha, F. (2020). Pendidikan Dan Pelatihan: Konsep Dan Implementasi Pengembangan Sumberdaya Manusia. Jakarta: LDPress.

Paramita, R. P. (2018). Rapor Guru dalam Hasil Uji Kompetensi. Lokadata, 1. Retrieved from https://lokadata.id/artikel/rapor-guru-dalam-hasil-uji-kompetensi

Restendi, D., Nugraha, F., \& Trianto, A. (2020). Pengembangan Sistem Pelatihan Jarak Jauh Berbasis Moodle di Balai Diklat Keagamaan Bandung. Andragogi: Jurnal Diklat Teknis Pendidikan dan Keagamaan, 8(2), 540-552.

Riyan, D. (2020). How the Distance Learning can be a Solution during the Covid-19 Pandemic. International Journal of Asian Education (IJAE) by READ Institute, 1(3), 117-124.

Rizaldi, D. R. (2020). Analysis Application of Distance Learning as a Learning Solution From Home. ASIAN EDUCATION PREPRINT REPOSITORY.

Saputra, J. (2017). Kompetensi Pedagogik Guru, 10-11. Retrieved from https://pgsd.binus.ac.id/2017/12/31/kompetensi-pedagogik/

Setiawati, E. (2010). Perbedaan Peningkatan Self Regulates Learning Peserta DJJ Matematika dengan Diklat Matematika MTS Reguler di BDK Bandung 2009. Tatar Pasundan: Jurnal Diklat Keagamaan, IV, 591-599.

Strungă, A. (2015). Using virtual learning communities in shaping the professional identity of primary and preschool pedagogy specialization students : a knowledge management approach. Procedia - Social and Behavioral Sciences, 180(November 2014), 460-467. https://doi.org/10.1016/j.sbspro.2015.02.145

Sugiyono. (2004). Pengaruh Pembinaan Kepala Sekolah, Motivasi Kerja, dan Pengalaman Diklat Terhadap Kinerja Guru dalam Pembelajaran Bahasa Madura di SDN Kecamatan Bangkalan Kabupaten Bangkalan MAdura, VI-2004.

Sujadi, Y. Darma; Imam. (2014). strategi heuristik dengan pendekatan metakognitif dan invertigasi. Jurnal Pendidikan MIPA, 109-119.

Y. A. Prawira. (2019). Menakar Kemampuan Literasi Pedagogik Guru Sekolah Dasar dalam Sudut Pandang Kompetensi Guru. Retrieved from http://develearning.lan.go.id/?redirect $=0$

Yasin, A. (2011). PENGEMBANGAN KOMPETENSI PEDAGOGIK GURU PENDIDIKAN AGAMA ISLAM DI MADRASAH (Studi Kasus di MIN Malang 
I). $E l-Q U D W A H, O(0), 157-181$. 